\title{
Psychological Aspects of Comics as the Paraliterary Genres
}

\section{Психологічні аспекти коміксу як паралітературного жанру}

\section{Ernest Ivashkevych}

Ph.D. in Psychology, Assistant Professor of Department of Practice of English of Rivne State University of the Humanities, Translator, Rivne State University of the Humanities, Rivne (Ukraine)

ORCID ID: https://orcid.org/0000-0001-7219-1086

Researcher ID: F-3865-2019

E-mail: ivashkevych.ee@gmail.com

\section{Ернест Івашкевич}

Кандидат психологічних наук, викладач кафедри практики англійської мови, перекладач, Рівненський державний гуманітарний університет, м. Рівне (Україна)

\section{Liudmyla Komarnitska}

Ph.D. in Philology, Lecturer of the Department of Social Work and Psychology, Podilskyi Special Educational and Rehabilitation Social-Economical College, Kamianets-Podilskyi (Ukraine)

ORCID ID: https://orcid.org/0000-0002-6742-8314

E-mail: kob-1974@ukr.net

\section{Людмила Комарніцька}

Кандидат філологічних наук, викладач кафедри соціальної роботи та психології, Подільський спеціальний навчально-реабілітаційний соціально-економічний коледж, м. Кам'янець-Подільський (Україна)

Address for correspondence, e-mail: kpnu_lab_ps@ukr.net Copyright: (c) Ivashkevych Ernest, Komarnitska Liudmyla

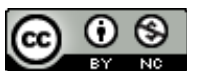
The article is licensed under CC BY-NC 4.0 International (https://creativecommons.org/licenses/by-nc/4.0/)

(C) Ivashkevych Ernest, Komarnitska Liudmyla

DOI (article): https://doi.org/10.32626/2227-6246.2020-49.106-130 
DOI: https://doi.org/10.32626/2227-6246.2020-49 2020. випуск 49

The contribution of the author: E. Ivashkevych - 50\%, L. Komarnitska-50\%. Авторський внесок: Е. Івашкевич - 50\%, Л. Комарніцька - 50\%.

\section{ABSTRACT}

The purpose of our article is: to define the main narratological devices and inventions made by Alan Moore and represented in his milestone novel, Watchmen, which may help us to define psychological aspects of comics as the paraliterary genres.

Methods of the research. As for general scientific methods the following ones are applied: the method of induction, deduction, analysis and synthesis, comparative and descriptive methods and explanatory ones.

The results of the research. The psychological characteristic of comics is the fact they do not have an omniscient narrator in the same way that traditional literature does, there isn't all-knowing all-seeing power behind the action. Comics use focalizers and narrators and point-of-view shots, which are an integral part of the narration of the graphic novel. One could argue that the omniscience of narration takes place in the visual depiction of the narrative when no focalization takes place and the images merely illustrate the actions from a clearly outside point of view. The reader is "pulled in» to the story, and only after a visible break in the narrative structure the reader once again becomes aware of the narrative structure and the discourse it applies and consequently uses different interpretational tools.

Conclusions. According to the results of our research we've maintained psychological aspects of comics as the paraliterary genres. The visual meaning of comics as the paraliterary genres is verbalized and narrativized through the language. Comics communicate in a "language» that relies on a visual experience common both to creator and the audience. The format of the comic book presents a montage of both the word and the image, and the reader is thus required to exercise both visual and verbal interpretive skills. The regimens of art (e. g. perspective, symmetry, brush stroke) and the regimens of literature (e. g. Grammar, plot, syntax) become superimposed upon each other.

Comic book experts still continue to stress the unique nature of reading abilities are required by comics, and the union of the word and the image has become even more centralized in contemporary studies of comics. Comics are seen as a language, even though the Grammar of this language is far from the completeness of the Grammar rules of a written language.

(C) Ivashkevych Ernest, Komarnitska Liudmyla DOI (article): https://doi.org/10.32626/2227-6246.2020-49.106-130 
DOI: https://doi.org/10.32626/2227-6246.2020-49

The single panel has traditionally been seen as the basic component of comic book narratives, and the action traditionally takes place from panel to panel. These transitions can be temporal, which include a clear transition and usually very little closure; this is the most common one in comic book narration. The transition can also be spatial, which consists of subject-to-subject change, where the panel shifts from one subject to another while still remaining in the same scene or idea. We have to stress that at this point, a degree of reader involvement is necessary to render these transitions meaningful. This type of transition is often very powerful, because it enables the writer to leave out dramatic actions deliberately, thereby increasing the level of suspense.

Also we distinguish various ways of combining words and images, from word specific (the pictures simply illustrate what the captions might say) to interdependent where only together do the words and pictures actually convey the message of a scene. Still, we'll admit that the possibilities are virtually unlimited.

Key words: comics, psychological aspects, paraliterary genres, combining words and images, temporal transitions, virtually unlimited possibilities, message of a scene, subject-to-subject change, visual interpretive skills, verbal interpretive skills.

\section{Introduction}

This research sets out to identify and analyze the various narrative structures and elements found in Watchmen, beginning with the textual and visual aspects. How do the narratological elements function in the text, how can they be identified, how should they be interpreted? How does a form such as comics affect the narrative and the meanings within, both political and ethical? The text consists of several types of textual narration, from the basic verbal narration in speech balloons to newspaper clippings and quotations from various fictitious literary sources, and all of these contribute to the narration of the graphic novel. The «superhero" characters in the comic are essential as well, both as focalizers and as means to deconstruct the traditional stereotype of a superhero as a genetic representation of the ubermensch. The various aspects of visual narration will be analyzed through theories from art (c) Ivashkevych Ernest, Komarnitska Liudmyla

DOI (article): https://doi.org/10.32626/2227-6246.2020-49.106-130 
history to basic comic book analysis of the single panel. Our research will not set out to cover the entire contents of Watchmen systematically, for the graphic novel is extensively wide and could be studied from various other points of view, such as the political perspective it offers of the Cold War-era America, or the way it chooses to depict its female heroines in a genre that is overtly masculine.

In addition, this research will not take part in the debate on the academic credibility of studying comics. As it often happens in the established scientific community the academics entering the field of science fiction (and by implication, comics), have traditionally felt their major task was to legitimate their object of study to the larger academic situation. This approach has been unfruitful in the long run, and has focused on the definition rather than description of the genre. The need to "prove oneself» in the face of the academic world is still with us, especially in the paraliterary genres, but it is not the aim of this thesis to validate comics as "art» or anything related to that discussion. As far as we know there exists no previous academic research on Watchmen, and the studies on the narratological aspects of graphic novels in general published so far are quite limited.

This research will for the most part refer to Alan Moore as the single "author» of Watchmen, and Dave Gibbons will be credited only when discussing the visual details and illustration. The reason for this is that Alan Moore concentrates on writing scripts while various talented artists illustrate his work in their own distinctive styles. This question of authorship related to graphic novels should not be overlooked as unproblematic; already G. Genette has confronted this problem: indeed, who is the "creator" of a comic page which was written by one person, penciled by another and inked, lettered (and perhaps colored or backgrounded) by still others? (Genette, 1980).

One reason why this thesis chooses to represent Moore as «the author» is because Moore is well-known for his scriptwri-

(C) Ivashkevych Ernest, Komarnitska Liudmyla DOI (article): https://doi.org/10.32626/2227-6246.2020-49.106-130 
DOI: https://doi.org/10.32626/2227-6246.2020-49 2020. випуск 49

ting, which involves extremely detailed information addressed to the illustrator concerning aspects such as panel division, overall mood and even the amount of words per panel. This is an essential dilemma when discussing the question of word and image - which of them is dominant? As numerous scientists have claimed throughout the ages, verbal language is "the native tongue of the narrative" and has to be regarded as such. Yet it is possible to admit that there are meanings which are better expressed through non-verbal means, and these meanings should not be declared a priori irrelevant to the narrative experience. In order to stay fair to the art form of comics, one must always acknowledge the primacy of writing, even though the preferred way being that the writer is also the illustrator. This is a question that brings forth several more, as such divisions as author / reader and script / text are far from simple and unproblematic. Crucial here is to realize that whether a combination of text and image or script and illustration, the result is always a dynamic process between the two components. In this thesis, Alan Moore and Dave Gibbons will be credited overall authorship for this detailed scriptwriting, but also for the sake of simplicity.

Watchmen as the sociocultural phenomenon has been studied in the courses of history, economy, politics and sociology, while there have been no linguistic study on the novel. Originally we planned to make an extended research on the linguistic peculiarities of Watchmen, but the composition proved to be so complex and multilayered, that in the very process of the research we decided to focus mostly on the narratological aspects of the novel. Still, the research has completely no analogues in our country, and probably a few in the world due to the complexity of the topic.

Actual importance of our research is proved by the constantly growing role of popular culture in general and comics media in particular. The profound study of Watchmen can rep(C) Ivashkevych Ernest, Komarnitska Liudmyla

DOI (article): https://doi.org/10.32626/2227-6246.2020-49.106-130 
resent this new point of view to our mentality media as one of the most promising from the academic understanding.

The object of the presented research is the graphic novel Watchmen written by Alan Moore and Dave Gibbons as a piece of non-ordinary, comic literature.

The subject of our research is the narratological aspects of various levels presented in the body of the composition of this novel.

According to these, the aim of this research is to define the main narratological devices and inventions made by Alan Moore and Dave Gibbons and represented in their milestone novel, Watchmen, which may help us to define psychological aspects of comics as the paraliterary genres.

In order to achieve the aim stated in our research, we have to complete a set of the following objectives: to make a set of methods appropriate to analyze visual narration; to outline the narratological importance of non-fiction and epigraphs presented in the novel; to investigate the role of extralingual devices in the course of the story narration; to point out the main features of the narrator's persona; to generalize the mechanics of temporal transitions in the novel's narration.

\section{Methods of the research}

Taking into account the importance of the conventional methods of linguistic research while dealing with the object of our article, the most substantial part of the methodological base for this research has been developed by us. As for general scientific methods, such of them as the method of induction, deduction, analysis and synthesis, comparative and descriptive methods and explanatory ones were used, quite successfully.

Methodological foundation of the presented research includes the articles of famous narratologists and theorists of Psychology. The rest has been done by the authors themselves, constantly using the following principles: the principle of stylistic distinction of the text; the principle of ideological and

(C) Ivashkevych Ernest, Komarnitska Liudmyla DOI (article): https://doi.org/10.32626/2227-6246.2020-49.106-130 
DOI: https://doi.org/10.32626/2227-6246.2020-49

2020. випуск 49

artistic point of view of the author; the principle of linguistic devices' analysis; the principle of integrity of this novel.

\section{Results and their discussion}

The study of visual narration has lately been of interest in the academic world. What makes the study of visual images challenging is the fact that the visual experience is described first and foremost with language; the visual meaning is verbalized and narrativized through language. One of the great early masters of comic books, S. Chatman was one of the first to demand comics the respect they deserve, both as an art form as well as an object worthy of serious academic study. His book, Story and Discourse. Narrative Structure in Fiction and Film (Chatman, 1978), is despite its twenty-plus years age still a valid aid when analyzing the very basic elements of comics, such as imagery, timing and framing, all of which are crucial in understanding and comprehending the building blocks of comics as a narrative medium. When one examines a comic book feature as a whole, the deployment of its unique elements takes on the characteristic of a language. Comics communicate in a "language» that relies on a visual experience common both to creator and audience. The format of the comic book presents a montage of both word and image, and the reader is thus required to exercise both visual and verbal interpretive skills. The regimens of art (e. g. perspective, symmetry, brush stroke) and the regimens of literature (e. g. grammar, plot, syntax) become superimposed upon each other.

Despite the fact that $\mathrm{S}$. Chatman produced his fundamental work a lot of years ago, this statement holds firm today. Comic book experts still continue to stress the unique nature of reading abilities comics require, and the union of word and image has become even more centralized in the modern study of comics. Comics are seen as a language, even though the Grammar of this language is far from the completeness of the Grammar rules of written language. Comic book narration in(C) Ivashkevych Ernest, Komarnitska Liudmyla

DOI (article): https://doi.org/10.32626/2227-6246.2020-49.106-130 
cludes aspects such as the composition of each page, which in turn affects the contents of that page. This creates the interplay between the content and the form, and the elements that are used to create comic book narration are so various that they do not create such limitations to the form as does the strictly written text. In the structural analysis of Watchmen and its narratological levels, this research will apply some of S. Chatman's observations on the "Grammar» of comics. It should also be pointed out that languages within this grammar alter greatly, and serve various different purposes - there exists no unified and single language within comics any more than in reality (Chatman, 1978).

Another «structuralist» approach that continues Chatman's ideas on the study of comics is Scott McCloud's acclaimed Understanding Comics. The Invisible Art (McCloud, 1993), in which S. McCloud attempts to develop comprehensive tools for comic book analysis, discussing the various ways and multiple levels comics work at S. McCloud's work is quite unique, narrated completely in comic book form, with McCloud's drawn alter ego illustrating the various problematic aspects related to comics with different visual examples. One that still works remarkably well is his demonstration of the power of the "gap" or the "gutter», the white line between the panels that requires active participation from the reader to construct the events taking place in the timelessness of the white void (McCloud, 1993: 66). Watchmen actually puns with the term gutter right at its beginning: "...the gutters are full of blood» (Moore \& Gibbons, 1987: I; 1). A. Moore \& D. Gibbons write the vigilante, while blood is indeed washing into the street gutter in the accompanying panel - but the panel edges close off the blood from the white "gutter», in which the only blood is the one the reader's imagination puts into it. The gutter is the place where the real action happens, and the metaphorical blood will seep back into the panels throughout the story, shading the panels with bloody pink. As Scott McCloud describes it, the

(C) Ivashkevych Ernest, Komarnitska Liudmyla DOI (article): https://doi.org/10.32626/2227-6246.2020-49.106-130 
gutter brings us the notion of closure, "the relation between the shown and the not shown, the stated and the implied, the articulated and the suggested» (McCloud, 1993: 67).

The single panel has traditionally been seen as the basic component of comic book narratives, and the action traditionally takes place from panel to panel. S. McCloud has divided these panel-to-panel transitions into six different categories, depending on the changes that take place between those two panels (McCloud, 1993: 70-74). These transitions can be temporal, which include a clear transition and usually very little closure; this is the most common one in comic book narration. The transition can also be spatial, which consists of subject-to-subject change, where the panel shifts from one subject to another while still remaining in the same scene or idea. $\mathrm{S}$. McCloud stresses that at this point, a «degree of reader involvement is necessary to render these transitions meaningful» (McCloud, 1993: 71). This type of transition is often very powerful, because it enables the writer / illustrator to deliberately leave out dramatic actions, thereby increasing the level of suspense. Scene-to-scene transitions, in which the change takes the reader across great distances, either in time or in space, are ones that, according to S. McCloud, require «deductive reasoning». Other transitions include shifts in aspects or transitions with no logical relationship whatsoever between the panels. This non-sequitur type of transition is very rare, as comic book narration is largely based precisely on sequential imagery of events and action in time and space. These transitions are the very building blocks of comic book narration, and will serve as a logical starting point in the analysis of the visual narration in Watchmen. S. McCloud also distinguishes various ways of combining words and images, from word specific (the pictures simply illustrate what the captions might say) to interdependent where only together do the words and pictures actually convey the message of a scene. Still, he ad(C) Ivashkevych Ernest, Komarnitska Liudmyla

DOI (article): https://doi.org/10.32626/2227-6246.2020-49.106-130 
mits that the possibilities are virtually unlimited (McCloud, 1993: 152-155).

As an option we can resort to slightly different classifications, presented in scientific literature, according to which we can refer to comics as iconotexts, by which the inseparable unity of word and image is meant. While developing it, we have used the ideas on general thought in order to develop terms to describe the two ways in which words and images work dynamically in comics: syntagmatic and paradigmatic. In a syntagmatic relationship both word and image support and complete each other, and the rules of the discourse (narration) are clear to the reader. This syntagmatic relationships can exist even when two separate narrational chains are combined, as often happens in Watchmen. A paradigmatic relationship, then, requires co-operation of the word and image that highlights the system in which it appears; word and image are contrasted and through the associations linked to this union, they create a meaning independent from the narrational chronology; this means that a picture or a panel can act as a metaphorical substitute to the events taking place in the narrative (Гончарук \& Онуфрієва, 2018a; Honcharuk \& Onufriieva, 2018b).

Watchmen borrows its visual look from the most typical of all comic book genres, the superhero comic exemplified by $\mathrm{Su}$ perman, the X-Men and the Fantastic Four. While generalizing the presentation style of this comic book subclass, some of the most typical aspects of the genre can be distinctively noticed, such as the handsome looks and the muscular body of the superhero, not to mention the brightly colored outfits, which are usually very tight and include a mask. The look that receives acceptance in fictional superhero comics receives a new meaning once transferred into the mundane world of Watchmen, especially when discussing the objectifying element in the outfit of the female superhero. As Laurie (formerly known as Silk Spectre) well describes: "You remember that costume? With that stupid little short skirt and the neckline going down to my

(C) Ivashkevych Ernest, Komarnitska Liudmyla DOI (article): https://doi.org/10.32626/2227-6246.2020-49.106-130 
navel? God, that was so dreadful» (Moore \& Gibbons: I; 25). Watchmen extrapolates with the idea of real-life superheroes, revealing the ridiculousness behind the romanticized idea of crime fighters.

The «super» in superhero has generally referred to the supernatural abilities of the superhero, such as the ability to fly or becoming invisible. It is noteworthy to point out that apart from one, the «superheroes» in Watchmen do not actually possess any supernatural abilities, but are in fact tragically human with very human problems. The «superheroes» are outsiders whom the American people neither trust nor understand. This can be located in the wider context of the development the superhero comics as a genre went through in the 1980s. The genre went through a transformation in which the clean-cut heroes of the past were replaced by a darker, more problematic and complex brand of superheroes. This transformation can be traced in the artful depiction of the real-life superheroes of Watchmen, who are carefully created in Moore's writing, and highlighted in the illustrations by Gibbons. In the following article, we will first investigate and analyze the basic narrative structures of both textual and visual narration with the combined aid of narratology and comic book analysis. We will focus more on the visual elements of narration in Watchmen, and also question the problematic of an omniscient narrator in the narrative form of a comic book. Also we will move beyond traditional structuralist approaches, and develop the question of madness and narration with the help of cognitive narratology and the idea of focalization in connection to visual narration. Finally, we will focus on the question of temporality and narration, especially through the character of Dr. Manhattan.

Comics do not have an omniscient narrator in the same way that traditional literature does, no all-knowing all-seeing power behind the action. Comics do use focalizers and narrators and point-of-view shots, which are an integral part of the narration of the graphic novel. One could argue that the (c) Ivashkevych Ernest, Komarnitska Liudmyla

DOI (article): https://doi.org/10.32626/2227-6246.2020-49.106-130 
omniscience of narration takes place in the visual depiction of the narrative when no focalization takes place and the images merely illustrate the actions from a clearly outside point of view. S. Chatman has resorted to film studies and calls this type of storytelling «Hollywood aesthetics», where the narration becomes "invisible» and the focus is on the events instead of the narration. According to $\mathrm{S}$. Chatman, the reader is «pulled in» to the story, and only after a visible break in the narrative structure does the reader once again become aware of the narrative structure and the discourse it applies and consequently use different interpretational tools. The question is not this simple, however (Chatman, 1978: 111). The omniscient narrator is one who knows about events occurring at any time or place, in complete detail, and not just about public events but also about the private thoughts and feelings of the characters (Mykhalchuk \& Ivashkevych, 2016). This statement does not hold when discussing the narration in Watchmen, as for example the traditional thought balloons depicting private thoughts are not shown at all to the reader.

The argument is that every story has a point of view, so there must be someone telling the story from that point of view. Watchmen creates an interesting dilemma here, for who is the person behind the collection of appendices? Who is the mysterious "we" that presents the excerpts from the various sources, some of them clearly of very private nature? The events are «filtered through» by a consciousness, which according to G. Genette makes the idea of «omniscience» impossible, as an omniscient narrator knows everything, past, present and future - with no need to have a point of view or a presentation of the events in a chronological order (Genette, 1980: 132). At this point we were obliged, in order to continue the research, to asemble the ideas of the «hierarchy of discourses» that reveal and conceal the amount of knowledge available to the reader by presenting the events of the story through «less knowledgeable» agencies such as various characters. Thus, we

(C) Ivashkevych Ernest, Komarnitska Liudmyla DOI (article): https://doi.org/10.32626/2227-6246.2020-49.106-130 
do not know any more about the plot as the events have been filtered through the experiences of characters; at least that would be the case we had not the appendices with their information. As the readers are equipped with the appendices, the readers are in possession of more knowledge than the characters, which positions the reader in an interesting position in the hierarchy of discourses in Watchmen. The fact that these hierarchies exist mean that choices are being made for the reader of the comics, events are presented in one way rather than another, which is the essence of narration itself. Every panel is a deliberate scene shown to us for a purpose of the narrative, the gutter closing every panel. So, who shows us the scenes, gives out the small clues to solve the mystery, who allows us a sudden access to the memories of the characters? Are these questions even relevant when discussing a medium as visual as comics? Our personal answer to the problematics of an omniscient narrator is to appeal to the author and his / her creative control, transferring the omnipotence to the author. Branigan, on the other hand, transfers this process to the reader, who creates and controls the narrative via acquiring knowledge divided by the text.

Naturally, the problem of omniscience is far more extensive to be thoroughly dealt with it in the present thesis, so let me just present the briefing of my point of view on this problem. Getting deeper into the matter of the question we may problematize the religious undertones linked with the term, as the usual analogy that is made between the author / narrator and God, and the basis for the idea is what we refer to as «Perfect Being Theory». The main problem in theology is the question of the compatibility of omniscience and free will, both which we claim are taken for granted as necessary and desirable. The idea of a "perfect being" is literally put to test in Watchmen, for the character of Dr. Manhattan is as close to God as a character can be: he is "omniscient» in a sense, for he knows all events past, present and future, and omnipotent (c) Ivashkevych Ernest, Komarnitska Liudmyla

DOI (article): https://doi.org/10.32626/2227-6246.2020-49.106-130 
as he potentially has the power to destroy the world (or save it). But omniscient characters and narrators differ greatly in their «readiness to share their unlimited knowledge with the reader». Dr. Manhattan does have access to Laurie's thoughts, as shown to us in the dialogue between him and Laurie in Chapter VIII:

«Jon? Oh Jesus, I... I, I mean they said you'd gone. They said you were on Mars...»

"I am on Mars. Now, I believe we have a conversation scheduled. You want to talk to me».

"God, yes. Yes, I was just thinking... But Jon, how did you know? I need to see you, you appear ... I mean, it's all so deus ex machina...» (Moore \& Gibbons, 1987: VIII; 23).

Omniscience is not a quantitative but a qualitative attribute: thus, if Dr. Manhattan has the ability to know the thoughts of one character, he must by definition be treated as knowing those of others. This claim is based on the assumption that the only alternative to a human's partial knowledge must be an omniscient God. However, we can imagine various versions of superior knowingness which are not limited to complete omniscience or human knowledge.

The implicit omniscience of Dr. Manhattan is also doubtful, for even though he has the access to other people's thoughts and an omnitemporal view of the past, present and future, the future is not as simple as it sounds. In Chapter IX, Dr. Manhattan talks of his future in very vague terms:

"I return to Earth at some point in my future. There are streets full of corpses. The details are vague» (Moore \& Gibbons, 1987: IX; 17).

The narrative also suggests at one point that Dr. Manhattan knew that President Kennedy would be assassinated, but yet he was seemingly powerless to prevent it, because to him, «the future is already happening» (Moore \& Gibbons, 1987: IV; 16). Everything is preordained, yet as an omnipotent character he could change the course of history. The character of Dr. Man-

(C) Ivashkevych Ernest, Komarnitska Liudmyla DOI (article): https://doi.org/10.32626/2227-6246.2020-49.106-130 
DOI: https://doi.org/10.32626/2227-6246.2020-49

hattan dramatizes well the untenability of an «omniscient» narrator, and forces to look for other ways to analyze his existence. One solution is to replace the heavily religious term "omniscience» with the idea of clairvoyance, more precisely telepathy. As we bear the opponent of every religious system in us, this fragment of our scientific personality criticizes the religious undertones that plague the term "omniscience», and suggests that telepathy opens up possibilities of a humbler, more precise, less religiously freighted conceptuality than does omniscience for thinking about the uncanniness of what is going on in narrative fiction. Telepathy is both thematically and structurally at work in the narratives of modern fiction, and calls for a very different kind of storytelling than that promoted by the religious, panoptical delusion of omniscience. This helps us understand that when characters' thoughts are reported, we are not dealing with a narrator who knows everything at once, but rather we should talk about «narrative instances» that report on one consciousness at a time, often transposing or translating the thoughts into the intermediate discourse.

The idea of telepathy instead of omniscience brings into discussion other elements as well, creating an effect of cognitive estrangement in the narrative as telepathy is linked with paranormal activities whereas the religious undertones of omniscience are more familiar with any reader born and raised in a western culture. So, is Dr. Manhattan an omniscient Godlike creature or a super-human with the super-human ability of telepathy? At one point he expresses his visions as follows:

"There's some sort of static obscuring the future, preventing any clear impression. The electromagnetic pulse of a mass warhead detonation might conceivably cause that...» (Moore \& Gibbons, 1987: IX; 17).

His knowledge appears to be more telepathy-like than omniscient, and as the later development in the novel shows, this «static» is actually caused by Adrian Veidt to prevent him (c) Ivashkevych Ernest, Komarnitska Liudmyla

DOI (article): https://doi.org/10.32626/2227-6246.2020-49.106-130 
from discovering his plot too soon [X; 11]. However, Dr. Manhattan's character does retain some aspects which link him to the concept of God, as he playfully suggests he will go and «create some» human life in another galaxy after leaving earth for good (Moore \& Gibbons, 1987: XII; 27). The questions of creation and free will arise repeatedly in Dr. Manhattan's narration, as he questions his actions:

A world grows up around me. Am I shaping it, or do its predetermined contours guide my hand? ... Without me, things would have been different. If the fat man hadn't crushed the watch, if I hadn't left it in the test chamber... Am I to blame, then? Or the fat man? Or my father, for choosing my career? Which of us is responsible? Who makes the world? (Moore \& Gibbons, 1987: IV; 27).

This question of making the world is a central theme in narratology, as the debate on "who makes the world?" is ever present. Is it the author, the narrator, the reader? The theme of power and responsibility entwines with the question of omnipotence. The question of symmetry and preservation of status quo are given new dimensions through the worldview of Dr. Manhattan, seeing the world acting as in clockwork, everything taking place as preordained. Dr. Manhattan's inability to relate to human life and continue resignation from the sphere of humanity places him in an interesting debate concerning God and whether or not God actually cares at all. Through Dr. Manhattan, Watchmen develops and discusses the idea of omniscience and all that is linked to it, including the dramatic change that follows from the appearance of something truly omnipotent and God-like the idea of divine omniscience is not really a model that helps us fathom the way authors and narrators works on literary fiction. Instead, the analogy seems to work the other way: The example of the novelist, who creates his world, peopling it with creatures who come to seem to us autonomous and who have interesting adventures, helps us to imagine the possibility of a creator, a god, a sentiment being,

(C) Ivashkevych Ernest, Komarnitska Liudmyla DOI (article): https://doi.org/10.32626/2227-6246.2020-49.106-130 
as undetectable to us as the novelist would be to the characters who exist in the universe of the text this god created.

This idea is not new in the field of literature, but has been repeatedly explored by authors such as James Joyce. In A Portrait of the Artist as a Young Man J. Joyce uses the internal monologue of Stephen Dedalus to discuss the role of the artist in connection to his work, an idea familiar from various other literary sources: "The artist, like the God of creation, remains within or behind or beyond or above his handiwork, invisible, refined out of existence, indifferent, paring his fingernails» (Joyce, 1999).

The vision of the indifferent, detached God «paring his fingernails» comes close to Dr. Manhattan's impartiality in the face of humanity. The omnipotent characters work like omnipotent authors, drawing up analogies to help us explain things we cannot explain.

\section{Conclusions}

So, according to the results of our research we've to maintain psychological aspects of comics as the paraliterary genres. These aspects are:

1. The visual meaning of comics as the paraliterary genres is verbalized and narrativized through the language. Comics communicate in a "language» that relies on a visual experience common both to creator and the audience. The format of the comic book presents a montage of both the word and the image, and the reader is thus required to exercise both visual and verbal interpretive skills. The regimens of art (e. g. perspective, symmetry, brush stroke) and the regimens of literature (e. g. Grammar, plot, syntax) become superimposed upon each other.

2. Comic book experts still continue to stress the unique nature of reading abilities are required by comics, and the union of the word and the image has become even more centralized in contemporary studies of comics. Comics are seen as a language, even though the Grammar of this language is (c) Ivashkevych Ernest, Komarnitska Liudmyla

DOI (article): https://doi.org/10.32626/2227-6246.2020-49.106-130 
far from the completeness of the Grammar rules of a written language. Comic book narration includes aspects such as the composition of each page, which in turn affects the contents of that page. This creates the interplay between the content and the form, and the elements that are used to create comic book narration are so various that they do not create such limitations to the form as strictly written text does.

3. The single panel has traditionally been seen as the basic component of comic book narratives, and the action traditionally takes place from panel to panel. These transitions can be temporal, which include a clear transition and usually very little closure; this is the most common one in comic book narration. The transition can also be spatial, which consists of subject-to-subject change, where the panel shifts from one subject to another while still remaining in the same scene or idea. We have to stress that at this point, a degree of reader involvement is necessary to render these transitions meaningful. This type of transition is often very powerful, because it enables the writer to deliberately leave out dramatic actions, thereby increasing the level of suspense.

4. Scene-to-scene transitions, in which the change takes the reader across great distances, either in time or in space, are ones that require deductive reasoning. Other transitions include shifts in aspects or transitions with no logical relationship whatsoever between the panels. This non-sequitur type of transition is very rare, as comic book narration is largely based precisely on sequential imagery of events and action in time and space. These transitions are the very building blocks of comic book narration, and will serve as a logical starting point in the analysis of the visual narration in Watchmen.

5. Also we distinguish various ways of combining words and images, from word specific (the pictures simply illustrate what the captions might say) to interdependent where only together do the words and pictures actually convey the message

(C) Ivashkevych Ernest, Komarnitska Liudmyla DOI (article): https://doi.org/10.32626/2227-6246.2020-49.106-130 
DOI: https://doi.org/10.32626/2227-6246.2020-49 2020. випуск 49 of a scene. Still, we'll admit that the possibilities are virtually unlimited.

6. There are two main ways in which words and images work dynamically in comics: syntagmatic way and paradigmatic one. In a syntagmatic relationship both the word and the image support and complete each other, and the rules of the discourse (narration) are clear to the reader. This syntagmatic relationships can exist even when two separate narrational chains are combined, as often happens in Watchmen. A paradigmatic relationship requires co-operation of the word and the image that highlights the system in which it appears; the word and the image are contrasted and through the associations linked to this union, they create a meaning independent from the narrational chronology; this means that a picture or a panel can act as a metaphorical substitute to the events taking place in the narrative.

The scientific originality and the theoretical importance of our research are presented through the completely original approach on the analysis of visual narration which is neither theatrical nor cinematic, so as graphic novel is a completely different media with its own unique nature, structure and mechanics.

The practical importance of our research is that the thesis may be used as the informational source to study contemporary Psychology, World Literature or Cinema Art (as the most important extralingual narration appears now in different spheres of our life), to write research papers on narratology, to provide writers and the scriptwriters with substantial devices for their researches, and to propose scientific methods developed in our research which may have their external further usage in Psycholinguistic and Literary Studies.

\section{Literature}

Гончарук Н., Онуфрієва Л. Психологічний аналіз рівнів побудови комунікативних дій. Psycholinguistics. Психолінгвістика. Психолинг-

(C) Ivashkevych Ernest, Komarnitska Liudmyla

DOI (article): https://doi.org/10.32626/2227-6246.2020-49.106-130 
вистика. 2018. Вип. 24 (1). С. 97-117. DOI 10.31470/2309-17972018-24-1-97-117.

Chatman, S. (1978). Story and Discourse. Narrative Structure in Fiction and Film. New York : Cornell University Press. 98 p.

Genette, G. (1980). Narrative Discourse. An Essay in Method. J. E. Lewin (Trans.). New York : Cornell University Press. 136 p.

Joyce, J. (1999). A Portrait of the Artist as a Young Man. URL : https:// www.sparknotes.com/lit/portraitartist/.

McCloud, S. (1993). Understanding Comics. The Invisible Art. New York : HarperCollins. $220 \mathrm{p}$.

Moore, A., \& Gibbons, D. (1987). Watchmen. London : Titan Books (DC Comics). 108 p.

Mykhalchuk, N. O., \& Ivashkevych, E. E. (2016). Psycholinguistic characteristics of visual narrative discourse. Психологія: реальність $i$ перспективи: Зб. наук. праць. Рівне : РДГУ. Вип. 7. С. 146-149.

Honcharuk, N., \& Onufriieva, L. (2018). Communicative needs in the structure of the intercourse process. Fundamental and Applied Researches in Practice of Leading Scientific Schools, 27 (3), 111-116. URL : https://farplss.org/index.php/journal/article/view/373.

\section{References}

Honcharuck, N., \& Onufriieva, L. (2018). Psykholohichnyi analiz rivniv pobudovy komunikatyvnykh dii [Psychological analysis of levels of communicative actions' constructing]. Psykholinhvistyka. Psikholingvistika. Psycholinguistics - Psycholinguistics. Psycholinguistics. Psycholinguistics, 24 (1), 97-117. DOI 10.31470/2309-1797-201824-1-97-117 [in Ukrainian].

Chatman, S. (1978). Story and Discourse. Narrative Structure in Fiction and Film. New York : Cornell University Press.

Genette, G. (1980). Narrative Discourse. An Essay in Method. J. E. Lewin (Trans.). New York : Cornell University Press.

Joyce, J. (1999). A Portrait of the Artist as a Young Man. Retrieved from https://www.sparknotes.com/lit/portraitartist/.

McCloud, S. (1993). Understanding Comics. The Invisible Art. New York : HarperCollins.

Moore, A., \& Gibbons, D. (1987). Watchmen. London : Titan Books (DC Comics).

Mykhalchuk, N. O., \& Ivashkevych, E. E. (2016). Psycholinguistic characteristics of visual narrative discourse. Psykholohiia: realnist $i$ perspektyvy - Psychology: reality and perspectives: Collection of research papers, 7, 146-149. Rivne : RDGU.

(C) Ivashkevych Ernest, Komarnitska Liudmyla

DOI (article): https://doi.org/10.32626/2227-6246.2020-49.106-130 
DOI: https://doi.org/10.32626/2227-6246.2020-49 2020. ВиПУСК 49

Honcharuk, N., \& Onufriieva, L. (2018). Communicative needs in the structure of the intercourse process. Fundamental and Applied Researches in Practice of Leading Scientific Schools, 27 (3), 111-116. Retrieved from https://farplss.org/index.php/journal/article/ view/373.

Івашкевич Ернест, Комарніцька Людмила. Психологічні аспекти коміксу як паралітературного жанру

\section{АНОТАЦІЯ}

Мета статmі - визначити основні наратологічні засоби та механізми, експліковані Аланом Муром і Дейвом Гіббонсом і представлені в романі «Нічні охоронці», що може допомогти нам з'ясувати психологічні аспекти коміксів як паралітурного жанру.

У роботі використано загальнонаукові методи дослідження, такі як методи індукції, дедукції, аналізу та синтезу, методи порівняння й опису, метод обгрунтування тощо.

Результати дослідження. У дослідженні показано, що психологічною особливістю коміксів $\epsilon$ те, що у них не існує оповіді від автора, як це, зазвичай, прийнято у традиційній літературі, немає діяльності, що актуалізує особистість. Психологічний вплив у коміксах належить фокалізаторам та оповідачам, які візуально зображені на картинках і $\epsilon$ невід'ємною частиною оповіді графічного роману. Доведено, що завдяки візуальній презентації матеріалу великою мірою відбувається розуміння оповіді, яке розпочинається вже у момент сприймання читачем візуальних зображень, у випадках, коли не відбувається безпосередньо фокалізації, а зображення просто ілюструють певні дії або діяльність із суто зовнішньої точки зору. Читач ніби "втягується» в історію, і лише після суттєвого "розриву» процесу сприймання особистістю візуального матеріалу та структури розповіді читач укотре усвідомлює структуру чієї оповіді, завдяки чому досягається ії розуміння. Останнє, як правило, набуває структури дискурсивного розуміння, що значною мірою актуалізується завдяки досить різним механізмам інтерпретації графрічного роману.

Висновок. За результатами дослідження виокремлено психологічні аспекти коміксів як паралітературних жанрів. Зазначено, що візуальне значення коміксу як паралітературного жанру вербалізується та нара(C) Ivashkevych Ernest, Komarnitska Liudmyla

DOI (article): https://doi.org/10.32626/2227-6246.2020-49.106-130 http://journals.uran.ua/index.php/2227-6246 
тивізується через мову. Комікси поєднані “мовою», що орієнтується на візуальний досвід особистості, спільний як для автора твору, так і для читача. Формат коміксу являє собою фотографію як слів, так і зображень, а тому читачеві слід виявити як візуальні, так і словесні навички інтерпретації. У розумінні графічного роману психологічні механізми мистецтва (наприклад, перспектива, симетрія, малюнки загалом) і психолінгвістичні механізми розуміння тексту (наприклад, граматика, сюжет, синтаксис) «накладаються» один на одного.

Автори коміксів ніби наголошують на унікальній здатності здібностей читача, яких вимагає побудова візуального матеріалу, його поєднання із словесним тощо, а ремікс слова й образу стає більшою мірою централізованим у сучасних дослідженнях коміксів. Останні розглядаються як мова, навіть якщо граматика цієї мови далеко не наповнюється граматичними правилами писемної мови.

Графічний роман із психологічної точки зору розглядається як основний компонент цілісних оповідань у картинках, а його дія традиційно відбувається послідовно. Ці переходи можуть бути тимчасовими, що включають чіткий перехід $і$, як правило, сюжет твору залишається відкритим. Перехід від однієї частини твору до іншої також може характеризуватися просторовими особливостями сприйняття роману, що відбувається внаслідок руху сприймання особистості від предмета до предмета, від одного суб'єкта до іншого, i, при цьому, фіксується в парадигмі однієї сцени або ідеї. У сприйманні та розумінні графічних романів важливою є максимальний ступінь залучення читача, інакше переходи від однієї сцени або ідеї до іншої нівелюються, що призведе до втрати розуміння сенсу загалом. Такий перехід є вельми суттєвим, проте достатньою мірою вагомим, адже дозволяє письменнику свідомо випускати з тексту окремі драматичні дії, тим самим значно посилюючи рівень текстової інтениії.

Також наголошено на психологічному змісті впливу на читача різних способів поєднань слів, візуальних зображень, символів тощо, починаючи від конкретних, окремих слів (малюнки лише ілюструють те, про що свідчать підписи) до взаємозалежних, поєднаних між собою в смисловому плані фраз, коли, насамперед, слова й малюнки насправді передають змістовий і смисловий плани сценічного зображення подій.

Ключові слова: комікси, психологічні аспекти, паралітературні жанри, поєднання слів і образів, тимчасові переходи, віртуально нелімітовані

(C) Ivashkevych Ernest, Komarnitska Liudmyla DOI (article): https://doi.org/10.32626/2227-6246.2020-49.106-130 
DOI: https://doi.org/10.32626/2227-6246.2020-49 2020. ВипУСК 49

можливості, сценічні зображення, зміна одного предмета на інший, візуальні інтерпретативні навички, вербальні інтерпретативні навички.

\section{Ивашкевич Эрнест, Комарницкая Людмила. Психологические аспекты комикса как паралитературного жанра}

\section{АННОТАЦИЯ}

Цель статьи - определить основные наратологические средства и механизмы, эксплицированные Аланом Муром и Дэйвом Гиббонсом в романе "Ночные охранники», что должно было фасилитировать определение нами психологических аспектов комиксов как паралитературного жанра.

В работе использованы основные научные методы исследования, такие как методы индукции, дедукции, анализа и синтеза, методы сравнения и описания, метод обоснования.

Результаты исследования. В исследовании показано, что психологической особенностью комиксов является то, что в их содержании не существует повествования от автора, как это обычно принято в традиционной литературе, поэтому не актуализируется ни личность, описанная в произведении, ни ее деятельность. Психологическое воздействие в комиксах принадлежит фокализаторам и рассказчикам, которые визуально изображены на картинках. Последние являются неотъемлемой частью повествования графического романа. Доказано, что благодаря визуальной презентации материала во многом происходит понимание повествования читателем, которое начинается уже в момент восприятия им визуальных изображений, когда непосредственно не актуализируется процесс фокализации, а изображения просто иллюстрируют определенные действия или деятельность, исходя из чисто внешних моментов. Читатель как бы “втягивается» в историю, и только после существенного "разрыва» процесса восприятия личностью визуального материала и структуры повествования читатель осознает структуру данного рассказа, благодаря чему достигается его понимание. Последнее, как правило, принимает структуру дискурсивного понимания, которое во многом актуализируется благодаря весьма различным механизмам интерпретации графического романа.

Вывод. Исходя их результатов исследования, были выделены психологические аспекты комиксов как паралитературного жанра. Отме(C) Ivashkevych Ernest, Komarnitska Liudmyla

DOI (article): https://doi.org/10.32626/2227-6246.2020-49.106-130 
DOI: https://doi.org/10.32626/2227-6246.2020-49 2020. випУСК 49

чено, что визуальное значение комикса как паралитературного жанра вербализируется и наративизируется благодаря лингвистическим средствам. Комиксы объединены “языком», который во многом ориентируется на визуальный опыт личности, приемлемый как для автора произведения, так и для читателя. Формат комикса представляет собой своеобразное фотографическое эксплицирование как слов, так и изображений, поэтому читателю следует проявить как визуальные, так и словесные навыки интерпретации. В понимании графического романа психологические механизмы искусства (например, перспектива, симметрия, рисунки) и психолингвистические механизмы понимания текста (например, грамматика, сюжет, синтаксис) «накладываются» друг на друга.

Показано, что авторы комиксов как будто подчеркивают уникальные способности читателя, которые требуют определенное построение визуального материала, его сочетание со словесным, а ремикс слова и образа становится в больщей степени централизованным в современных исследованиях комиксов. Последние рассматриваются как лингвистические средства, даже если грамматика этого языка далеко не наполняется грамматическими правилами письменной речи.

Доказано, что графический роман с психологической точки зрения рассматривается как основной компонент целостных рассказов в картинках, а его действие традиционно проходит последовательно. Эти переходы могут быть временными, включающими четкий переход от одних фреймов к другим, и, как правило, сюжет остается открытым. Переход от одной части произведения к другой также может характеризоваться пространственными особенностями восприятия романа, что происходит вследствие движения восприятия личности от предмета к предмету, от одного субъекта к другому, и, при этом, фиксируется в парадигме одной сцены или идеи. В восприятии и понимании графических романов важной является максимальная степень привлечения читателя, иначе переходы от одной сцены или идеи к другой нивелируются, что может привести к потере понимания смысла в целом. Такие переходы являются весьма существенными, однако в достаточной степени важными, поскольку позволяют писателю сознательно выпускать из текста отдельные драматические действия, тем самым значительно усиливая уровень текстовой интенции.

Также подчеркнуто психологическое содержание различных способов воздействия на читателя сочетаний слов, визуальных изображений

(C) Ivashkevych Ernest, Komarnitska Liudmyla DOI (article): https://doi.org/10.32626/2227-6246.2020-49.106-130 
DOI: https://doi.org/10.32626/2227-6246.2020-49 2020. випУСК 49

и символов, начиная от конкретных, отдельных слов (рисунки лишь иллюстрируют то, о чем свидетельствуют подписи) и заканчивая взаимосвязанными, объединенными между собой в смысловом отношении фразами, когда, прежде всего, слова и рисунки на самом деле передают содержательный и смысловой планы сценического изображения событий.

Ключевые слова: комиксы, психологические аспекты, паралитературные жанры, сочетания слов и образов, временные переходы, виртуально нелимитированные возможности, сценические изображения, изменение одного предмета на другой, визуальные интерпретативные навыки, вербальные интерпретативные навыки.

Original manuscript received April 13, 2020

Revised manuscript accepted May 21, 2020

(C) Ivashkevych Ernest, Komarnitska Liudmyla

DOI (article): https://doi.org/10.32626/2227-6246.2020-49.106-130 http://journals.uran.ua/index.php/2227-6246 